\title{
Post-Commencement Finance - Domiciled Resident or Uneasy Foreign Transplant?
}

\author{
H Stoop ${ }^{\star}$ and A Hutchison ${ }^{\star \star}$
}

\section{P.E.R}

Pioneer in peer-reviewed, open access online law publications.

Author

Helena Stoop

Andrew Hutchison

Affiliation

University of Cape Town

South Africa

Email

helena.stoop@uct.ac.za

andrew.hutchison@uct.ac.za

Date published

31 March 2017

Editor Prof K Beiter

How to cite this article

Stoop $\mathrm{H}$ and Hutchison A "Post-

Commencement Finance -

Domiciled Resident or Uneasy

Foreign Transplant?" PER / PELJ

2017(20) - DOI

http://dx.doi.org/10.17159/1727-

3781/2017/v20i0a1370

Copyright

DOI

http://dx.doi.org/10.17159/1727-

$3781 / 2017 / v 20$ i0a1370

\section{Abstract}

The 2008 Companies Act 71 of 2008 introduced a new business rescue regime into South African company law, bringing it into line with trends in developed countries, particularly the United States. Indeed, it appears that the United States Chapter 11 model was followed in this process, introducing the business rescue concept as a legal transplant. Corporate law is well suited to legislative borrowing, but there are important caveats to bear in mind when doing so. In particular: the context and legal culture of the country of origin may differ from those of the destination country. South Africa's commercial environment is different from that of the United States, problematising a transplant of Chapter 11 's concepts. Post-commencement finance will be used as a micro-study of this broader phenomenon, and this topic will be investigated with comparative reference to the position in the United States. It will be argued that an essential difference between the two procedures is the lack of legislatively mandated court oversight in South Africa. This impacts on the interests of creditors, as well as on the availability of fresh finance. This results in problems in the implementation of the postcommencement finance provisions, which threaten the viability of this particular legal transplant.

\section{Keywords}

Company law; business rescue; post-commencement finance; secured credit; United States Chapter 11; legal transplants; court oversight. 


\section{Introduction}

"The law, it seems, is an eager and experienced traveler", ${ }^{1}$ and in the case of Chapter 6 of the South African Companies Act" ("the Act" or "the South African Act") it would appear that United States bankruptcy law has made its way to our shores. Academics and practitioners are by now familiar with this chapter of the Act, which deals with business rescue. ${ }^{3}$

Business rescue, or corporate reorganisation, has become a common phenomenon in developed jurisdictions. ${ }^{4}$ It would appear that the benefits of this type of approach seem to be generally viewed as outweighing the drawbacks. ${ }^{5}$ Chapter 6 of the Act sought to update South African company law in line with developments in other countries. ${ }^{6}$ The purpose section of the $\mathrm{Act}^{7}$ reiterates aims set out in the 2004 policy paper prepared by the Department of Trade and Industry (DTI) and entitled "South African Company Law for the $21^{\text {st }}$ Century: Guidelines for Corporate Law Reform". 8 This policy paper emphasised an intention to develop a business rescue regime appropriate to the needs of the current South African economy and

Helena Stoop LLB (Pret) LLM (Stell). Senior Lecturer in the Department of Commercial Law, University of Cape Town, South Africa; PhD candidate, Durham Law School, United Kingdom. Email helena.stoop@uct.ac.za.

** Andrew Hutchison BA LLB LLM PhD (UCT). Associate Professor in the Department of Commercial Law, University of Cape Town, South Africa. Email andrew.hutchison@uct.ac.za.

$1 \quad$ Markovits 2005 Cornell Int'l LJ 95.

2 Companies Act 71 of 2008 ("the Act").

3 For general discussions of the provisions of ch 6, see Cassim et al Contemporary Company Law ch 18; Rushworth 2010 Acta Juridica 375-408; Bradstreet 2011 SALJ 352-380; Loubser 2013 SA Merc LJ 435-457.

$4 \quad$ See for example Emmerman 2015 Am Bankr Inst J 26-28; Metzger and Bufford 1993 Cal Bankr J 153-159; Wessels 2014 Insolvency Intelligence 4-9.

5 The rationale for this type of approach is that the greater good of the enterprise as a whole should take precedence over an individual creditor's interests. The liquidation of a major corporation will result in job losses, which may have a negative impact on the economic status of a geographical location if a city depends on the resident corporation. Also there will be losses to shareholders. Thus business rescue, if successful, is certainly in the public interest. Even creditors may benefit, since the value of a business's assets is usually greater if it remains a going concern - or even if it is sold as a going concern - than if it is liquidated and its assets sold off piecemeal. For a defence of business rescue as a concept, see McCormack Corporate Rescue Law ch 1. For a contrary view, see Loubser 2013 SA Merc LJ 435-457, who points out that it should not be accepted without question that liquidation proceedings necessarily produce less favourable outcomes.

$6 \quad$ See the discussion in Rajak and Henning 1999 SALJ 263-264.

7 One of the express purposes of the new Companies Act at $\mathrm{s} 7(\mathrm{k})$ is to "provide for the efficient rescue and recovery of financially distressed companies, in a manner that balances the rights and interests of all relevant stakeholders". GN 1183 in GG 26493 of 23 June 2004. 
mentions specifically that the United States model found in Chapter 11 of that country's Bankruptcy Code ${ }^{9}$ would be considered. ${ }^{10}$

It is also not surprising that the legislature chose to consult United States law and to consider incorporating (at least in part) the Chapter 11 process. As Loubser ${ }^{11}$ points out, Chapter 11 reorganisation has "reached cult status", with an overwhelming number of jurisdictions in Europe and elsewhere choosing to consider, rely on, and incorporate its processes and provisions. The prevailing school of thought seems to be that the success of this mechanism in the United States endorses its value as a legal transplant. ${ }^{12}$

Given this, and the relative maturity of the United States corporate rescue regime, one would be forgiven for considering this regime a valuable source of insight that our courts might draw on for guidance when interpreting the provisions of Chapter 6 of the Act. However, the Supreme Court of Appeal in African Banking Corporation of Botswana $v$ Kariba Furniture Manufacturers ${ }^{13}$ was unwilling to do so for a number of reasons. This article will not analyse the substance of the decision in the Kariba case, but instead considers the court's reluctance to look to the United States' Chapter 11 and the jurisprudence thereunder when interpreting the provisions of the South African Act's Chapter 6. The Supreme Court of Appeal did not, however, conclude that as a general rule American jurisprudence should not be considered, but merely that it was inappropriate to do so in the instance before it. ${ }^{14}$ We contend that this might well also be the case for several other provisions of Chapter 6. Although the Act expressly provides that courts may look to foreign company law to inform their decisions to the extent that this is appropriate, ${ }^{15}$ close analysis shows that they should proceed with caution in the case of Chapter 11 of the United States code. This paper will defend this view by means of a comparative analysis of the United States and South African positions on post-commencement financing.

9 Chapter 11 was introduced into US corporate insolvency law by the Bankruptcy Reform Act, 1978. The United States federal law on bankruptcy may be found in Title 11 "Bankruptcy" of the United States Code (hereafter "the Bankruptcy Code").

10 GN 1183 in GG 26493 of 23 June 200445.

11 Loubser 2013 SA Merc LJ 439.

12 Loubser 2013 SA Merc LJ 440. More extensive discussion of legal transplantation follows in part 4.2 below.

13 African Banking Corporation of Botswana v Kariba Furniture Manufacturers 20155 SA 192 (SCA) (hereafter Kariba).

14 Kariba para 16.

15 Section 5(2) of the Act. 
This paper will not purport to consider the merits of Chapter 11 as a legal transplant in South Africa, however. A subtle yet pervasive import of the features of this system is a fait accompli. Instead, now that Chapter 11 has been incorporated into South African company law, the paper will question whether a similar positive impact of the business rescue concept is possible in South Africa under the existing statutory provisions of Chapter 6 of the Act. Primarily, the paper will caution against a process of statutory interpretation that imports features of United States law without careful consideration of the significant differences between the Act and Chapter 11. In considering the case of post-commencement finance it becomes clear that judges may be confined and restricted by the wording of the Act in a manner that no interpretation can remedy, regardless of how progressive or robust it may be. Indeed, attempts to fill the gaps by importing from United States law could cause as much damage to the reputation of Chapter 6's provision as a conservative, textual approach. ${ }^{16}$

Part Two of the article will provide an overview of the relevant provisions of Chapter 11 of the United States Code and describe recent developments in the United States that are relevant to the discussion. Following this, in Part 3 , the post-commencement financing provisions of the South African Act will be discussed and analysed in the light of cases that have considered these sections. In Part Four the approach taken by the Supreme Court of Appeal in Kariba will serve as a point of departure to comment briefly on the debate surrounding so-called legal transplants and how these manifest in the context of corporate law in general and specifically in the context of insolvency law and post-commencement finance during business rescue proceedings. The comparative analysis illustrates that a greater degree of oversight by the courts, perhaps unexpectedly, renders the United States system flexible and practical, as will be argued in the conclusion in Part Five.

\section{Post-petition finance in the United States}

\subsection{Chapter 11 reorganisation in general}

Chapter 11 of the Bankruptcy Code was enacted in 1978; hence the comment by LoPucki and Triantis that it is a "mature" system. ${ }^{17}$ Chapter 11

16 See for example Osode 2015 Penn State $J$ L Int'I Affairs 459, where the author argues that "the adoption of an interpretive approach that is conservative, largely textual or literal, and purpose-neutral will significantly undermine the prospect of Chapter Six achieving the public policy goals intended by law and policymakers. Indeed, such an approach may by itself lead to regulatory failure".

17 LoPucki and Triantis "Systems Approach" 120. 
proceedings usually commence with the filing of a petition by the distressed company with the bankruptcy court. ${ }^{18}$ Once such proceedings begin, a moratorium ("automatic stay") is placed on litigation and executions against the petitioning company. ${ }^{19}$ The company is then able to meet with creditors and shareholders to reorganise debt and restructure the company if necessary. ${ }^{20}$ Reorganisation proceedings under Chapter 11 are referred to as "debtor in possession" ("DIP"), with the management structures of the company remaining in place, but with the same functions and duties as a trustee in conventional bankruptcy proceedings. ${ }^{21}$ The DIP must then draw up a reorganisation plan, which is to be approved by creditors. ${ }^{22}$ There is provision for a "cram down" of dissenting creditors, provided a sufficient majority is in favour thereof. ${ }^{23} \mathrm{~A}$ cram down occurs when a court orders that a business rescue plan should be implemented, despite the objection of a dissenting class of creditors.

\subsection{Post-petition finance under Chapter 11}

One of the administrative powers of the DIP is to obtain post-petition finance to revitalise the debtor corporation. ${ }^{24}$ The terms on which such finance can be obtained are set out in section 364 of the Bankruptcy Code. This section establishes four progressive tiers of financing, which create greater and greater encumbrances on the assets of the company in favour of the new lender. The idea is that the company attempts to obtain finance at the lowest level of encumbrance possible, so that if finance can be secured on easier terms within the mechanism of say section $364(a)$ or (b), there is no need to look to the protections which section 364(c) or (d) offer to the creditor. These tiers will be considered one by one.

Section 364(a) authorises the company to obtain unsecured credit in the ordinary course of business without court approval. This finance will enjoy the priority of an administrative expense and will thus rank above unsecured

18 This would occur in terms of $s 301$ of the Bankruptcy Code. See McCormack Corporate Rescue Law 78-79.

19 Section 362 of the Bankruptcy Code.

20 Section 341 of the Bankruptcy Code.

21 Section 1107(a) of the Bankruptcy Code. See Armour, Cheffins and Skeel 2002 Vand $L$ Rev 1699 for a comparative analysis of US and UK law on corporate reorganisations from a corporate governance point of view.

22 Sections 1121-1129 of the Bankruptcy Code.

23 Section 1129 of the Bankruptcy Code. For more detailed analysis of US-style "cram downs" see Friedman 1992-1993 Cardozo L Rev; LoPucki and Triantis "Systems Approach" 160-170; Broude 1983-1984 Business Lawyer 441-454. 
creditors with a priority claim on the assets of the company. ${ }^{25}$ This means that the DIP may use funds to pay new creditors during reorganisation, since it is authorised to use the company's assets to meet administrative expenses. ${ }^{26}$ All pre-petition secured creditors are in the meantime blocked by the automatic stay. ${ }^{27}$ The "ordinary course of business" requirement is open to some interpretation: Henoch suggests a fairly literal interpretation of what is considered usual in a business's day-to-day operations. ${ }^{28}$ This would exclude servicing debt or purchasing new capital assets. ${ }^{29}$

Section 364(b) authorises the obtaining of unsecured credit with administrative expense priority for uses other than in the ordinary course of business, provided there is "notice and a hearing". This requires the existing creditors to be informed of the pending application and for the new finance to be court-approved. This is unlikely to be the favoured option for postpetition creditors, however, since by definition the funds are required for unusual outlays and hence it would be prudent to obtain further security under section $364(\mathrm{c})$ or $(\mathrm{d}) .{ }^{30}$

Post-petition secured credit is obtainable under section 364(c) or (d), following notice and a hearing, with the difference between these sections being that super-priority security can be taken only under section 364(d). There must be no possibility of obtaining finance allowable under section 364(a) or (b) as an administrative expense, however. ${ }^{31}$ Thus section 364(c) creates three options for new creditors:

- a claim ranking as the leading priority expense, before other administrative expenses. This would put the creditor first in line after the existing secured creditors;

- a lien on otherwise unencumbered property of the debtor company. This would create a new security interest in assets which were not affected by pre-petition secured creditor claims;

- a junior lien on already encumbered property.

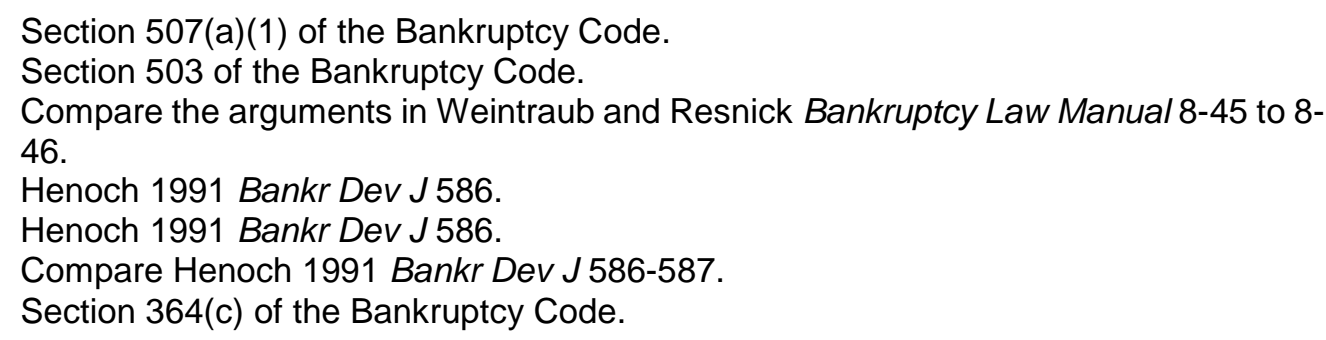


Henoch notes that most post-petition financing agreements in the USA operate under section 364(c). ${ }^{32}$ In order for this section to function, however, there must be value in the assets of the company over and above the existing claims of secured creditors. This is referred to as an "equity cushion" in the jurisprudence. It is the size of this equity cushion which is likely to induce a creditor to lend funds under section 364(c) without requiring super-priority. ${ }^{33}$ If the newly secured creditor is not first in the queue for payment, it would have to be demonstrated to its satisfaction that it is nevertheless guaranteed payment.

Where there is insufficient equity to satisfy a post-petition creditor or no unencumbered assets to use as security, section 364(d) of the Bankruptcy Code provides that a court may authorise a granting of "super-priority" finance which takes precedence over existing pre-petition secured claims. Section $364(d)$ reads as follows:

(d)(1) The court, after notice and a hearing, may authorize the obtaining of credit or the incurring of debt secured by a senior or equal lien on property of the estate that is subject to a lien only if -

(A) the trustee is unable to obtain such credit otherwise; and

(B) there is adequate protection of the interest of the holder of the lien on the property of the estate on which such senior or equal lien is proposed to be granted.

(2) In any hearing under this subsection, the trustee has the burden of proof on the issue of adequate protection.

As to leg A of section 364(d)(1), the case law suggests that the duty on the debtor to seek other forms of credit does not require it to approach every possible lender; the court must decide on a case-by-case basis whether the test has been met. The US Court of Appeal for the fourth circuit held in In re Snowshoe Company Inc ${ }^{34}$ that it was sufficient for the debtor corporation to have approached financial institutions in the immediate geographical area. ${ }^{35}$ This approach was echoed in In re Sky Valley Inc, ${ }^{36}$ where the corporation had identified potentially interested debtors as those holding a pre-petition security interest or doing business in the community surrounding the ski

Henoch 1991 Bankr Dev J 587.

Compare Henoch 1991 Bankr Dev J 588.

34 In re Snowshoe Company Inc 789 F 2d 1085 (Court of Appeal, Fourth Circuit 1986) (hereafter Snowshoe).

35 Snowshoe 1088.

36 In re Sky Valley Inc 100 BR 107 (Bankruptcy Court, Gainsville Division 1988) (hereafter Sky Valley). 
resort and golf course business operated by the debtor company. ${ }^{37}$ All identified lenders had been unsuccessfully approached and this was held to be adequate..$^{38}$ In In re Ames Department Stores $I n c^{39}$ the size of the loan required to fund the reorganisation of the debtor ( $\$ 250$ million) was such that only a limited number of potential lenders was available..$^{40} \mathrm{~A}$ denial of credit by four such lenders otherwise than under section 364(d) was therefore held sufficient to satisfy the requirements of that section. ${ }^{41}$

As to leg B, the concept of "adequate protection" is defined in section 361 . According to that section, adequate protection may be given by:

- requiring the debtor company to make periodic cash payments to the affected creditor where the automatic stay on enforcement actions against the creditor under section 362 - or the granting of a superpriority security interest under section 364 - has led to a decrease in the creditor's interest in the debtor's property. This would be particularly apt where a security interest is held in a depreciating asset and the automatic stay delays realisation of that interest;

- $\quad$ providing an additional or replacement lien on alternative property;

- $\quad$ providing alternative relief which will provide the creditor with the "indubitable equivalent" of its property. The US Supreme Court held in United Savings Association of Texas $v$ Timbers of Inwood Forest Associates $\mathrm{Ltd}^{42}$ that "indubitable equivalent" has developed a settled meaning "connoting the right of a secured creditor to receive present value of his security". ${ }^{43}$

The rationale behind the concept of adequate protection is said to be the protection of property rights in the United States Constitution. It is also for this reason that super-priority is not as drastic a measure as it appears to be at first glance. In In re Swedeland Development Group Inc ${ }^{44}$ the Court of Appeal for the Third Circuit stated that the enquiry as to whether protection

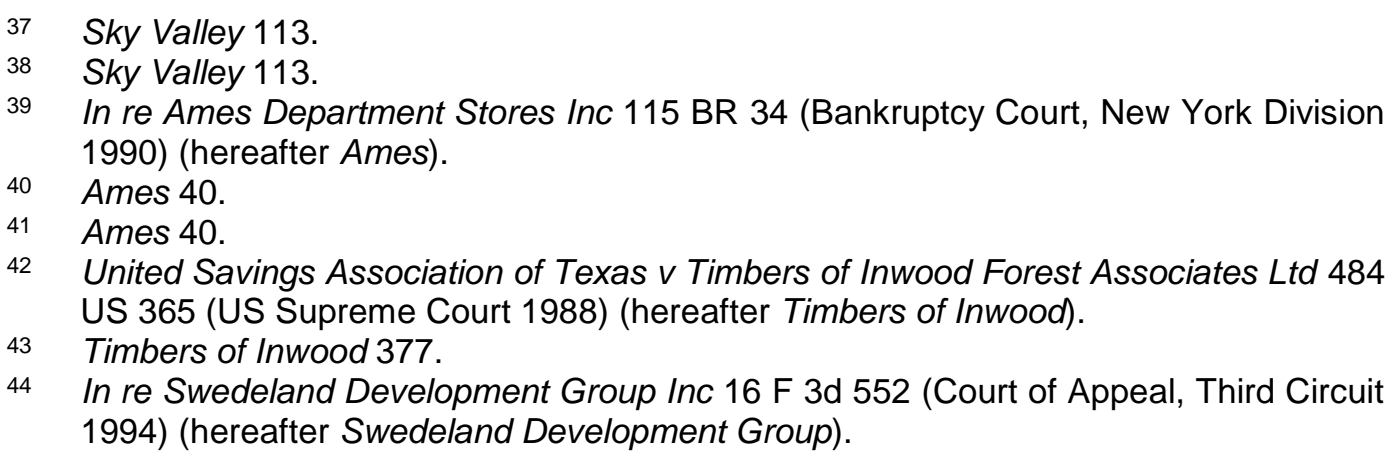

44 In re Swedeland Development Group Inc 16 F 3d 552 (Court of Appeal, Third Circuit 1994) (hereafter Swedeland Development Group). 
is adequate "depends directly on how effectively it compensates the secured creditor for loss of value caused by the super-priority given to the post-petition loan". ${ }^{45}$ An analysis of the case law indicates that this is the key determinative issue in a court's decision as to whether or not to grant finance.

One of the enduring tests as to whether there is adequate protection for prepetition creditors is to determine if there is sufficient equity in the assets of the company to protect existing secured creditors from an issue of fresh super-priority finance. ${ }^{46}$ This is the "equity cushion" test. An example of a case decided on the basis of an equity cushion analysis is Sky Valley. ${ }^{47}$ In this case the debtor sought emergency super-priority funding in the amount of $\$ 400000$. The total outstanding debt on a golf course development owned by the debtor company was approximately $\$ 11$ million. The value of the property hypothecated by the various security interests was about $\$ 12$ million. Thus the equity cushion was narrow. However, the only petitioning creditor (Anchor Bank) held a first priority security interest of about $\$ 3$ million of the total debt, which was secured to property totalling $\$ 8,5$ million dollars. Since the other creditors had not opposed the application for new section $364(d)$ credit, the equity cushion of over $\$ 5$ million was held alone to be sufficient protection to Anchor Bank, despite the fact that its claim would now be subordinated. ${ }^{48}$

A similar finding was reached in In re Dunes Casino Hotel. ${ }^{49}$ Here the debtor sought $\$ 700000$ in super-priority funds to aid in the development of a casino hotel at Atlantic City. The objecting creditor was exposed to the extent of $\$ 17,6$ million, a debt secured to property worth $\$ 26$ million. Again, the court held that the equity cushion alone was sufficient protection. ${ }^{50}$

In Snowshoe ${ }^{51}$ the court held that although some creditors viewed the equity cushion as part of the "bargained for consideration", the fact that liabilities of $\$ 13$ million were recorded against a ski resort development worth $\$ 20$ million provided sufficient cushion for a super-priority loan of a further $\$ 2$

45 Swedeland Development Group 564. This passage was approved in the later cases of In re Campbell Sod Inc 378 BR 647 (Bankruptcy Court, Kansas Division 2007) 653 and In re Fontainebleau Las Vegas Holdings LLC 434 BR 716 (District Court, Miami Florida Division 2010) (hereafter Fontainebleau) 749.

46 Telesca 1988 Bankr Dev J 117-128.

47 In re Sky Valley Inc 100 BR 107 (Bankruptcy Court, Gainsville Division 1988).

48 Sky Valley 114.

49 In re Dunes Casino Hotel 69 BR 784 (Bankruptcy Court, New Jersey Division 1986) (hereafter Dunes Casino Hotel).

50 Dunes Casino Hotel 795.

51 In re Snowshoe Company Inc 789 F 2d 1085 (Court of Appeal, Fourth Circuit 1986). 
million. This finding was based in part on the detailed financial projections of the debtor that the loan could be repaid in one ski season. ${ }^{52}$ These two factors together, held the court, amounted to adequate protection for the pre-petition creditor. ${ }^{53}$

Snowshoe was one of the earlier cases dealing with a section 364(d) application and the finding that more than an equity cushion alone was needed could in part be ascribed to the criticism of the equity cushion analysis in In re Alyucan Interstate Corp. ${ }^{54}$ In that case it was held that while the equity cushion analysis was easy to apply, a court needed to be able to take into account the individual facts of a case ${ }^{55}$ The court thus expressly rejected the concept of an equity cushion as a measure of whether there was adequate protection to creditors. ${ }^{56}$ This finding was based on the view:

- $\quad$ that equity cushion analysis was inconsistent with the concept of adequate protection expressed in section 361 , which was to guard against impairment of the lien;

- that the purpose of section 361 was to compensate for lost value due to the automatic stay. (Consider for example the payment of cash compensation to creditors who are barred from enforcing their claims.) The value from other assets might be appropriated to pay such compensation, rather than secure fresh debt;

- $\quad$ that equity should be used to rehabilitate debtors for the benefit of pre-petition creditors, not create new debt. ${ }^{57}$

The finding in Alyucan seems to have made waves in the case law and in the secondary sources. The points raised against equity cushion analysis are valid, but seem to present a conservative view in favour of pre-petition secured creditors at the expense of the debtor corporation. This view seems at odds with the rest of the body of case law. In defence of Alyucan, Telesca notes that the structuring of ordinary credit agreements takes into account available security and attendant risk and this calculation of risk ultimately determines the bargain struck between the parties. ${ }^{58}$ To uproot security

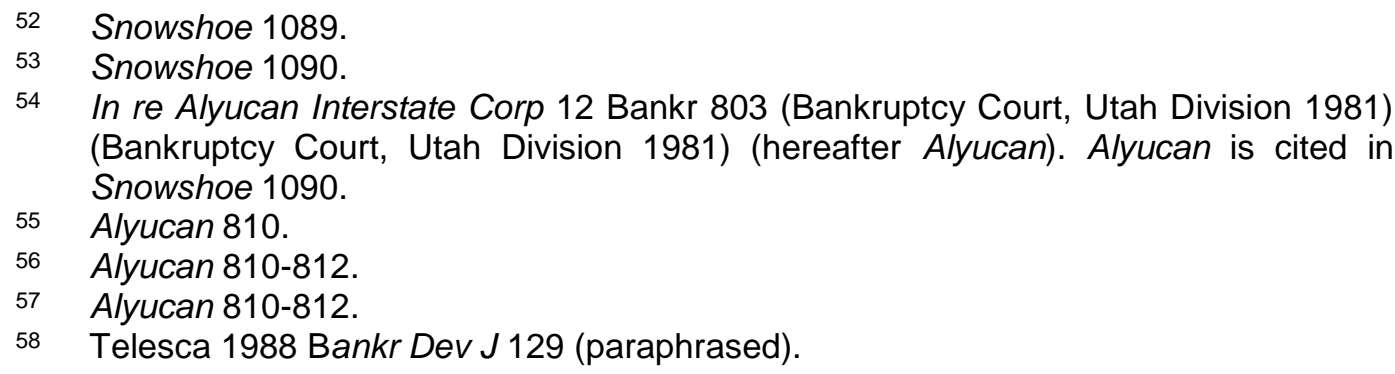


post-petition on the basis of an equity cushion, he argues, is "to change one side of the terms without commensurately changing the other". ${ }^{59}$ Telesca concludes that it would be "beneficial to all parties" if the courts adopted "a cautious and calculated approach to the particulars of each case". 60

This cautiousness is recognised in the Snowshoe judgment as set out above. Further criticism of equity cushion analysis was presented in In re Aqua Associates, ${ }^{61}$ where the court raised the issue of whether the going concern or liquidated valuation of the property was more appropriate, as well the problems in conflicting valuations from two teams of lawyers and experts. ${ }^{62}$ Furthermore such analysis could either "foolishly let the air out of an equity cushion" or deny permission to a debtor who lacks an equity cushion to enter a transaction which is "demonstrably wise and resourceful". ${ }^{63}$ The court held that the presence of an equity cushion should merely be a factor in the decision and the inquiry should focus on whether the protection of the secured creditor's interest was adequate (citing inter alia Alyucan). ${ }^{64}$ In Aqua Associates the equity cushion was modest, but it had a potentially viable business plan involving a lucrative lease of its premises to an upmarket billiards club. The debtor was permitted to access super-priority funding. ${ }^{65}$

Thus the case law reflects a certain amount of ambivalence between debtor and creditor interests, but the overall impression one gets is that reorganisation is viewed favourably by the courts. To this end an application for post-petition finance has a good prospect of success, provided the debtor can show the existence of an equity cushion and something more such as the potential viability of its future business plans. In some cases an equity cushion alone will be sufficient, but this will depend on the individual facts of a given case.

A final point to consider before leaving the discussion of section 364 is the impact of section 364(e). (Section 364(f) contains certain definitional limits on the concept of "security" for the purposes of the rest of the section which are not relevant to this paper.) Section 364(e) protects the good faith creditor under this section: its loan agreement (including possible super-

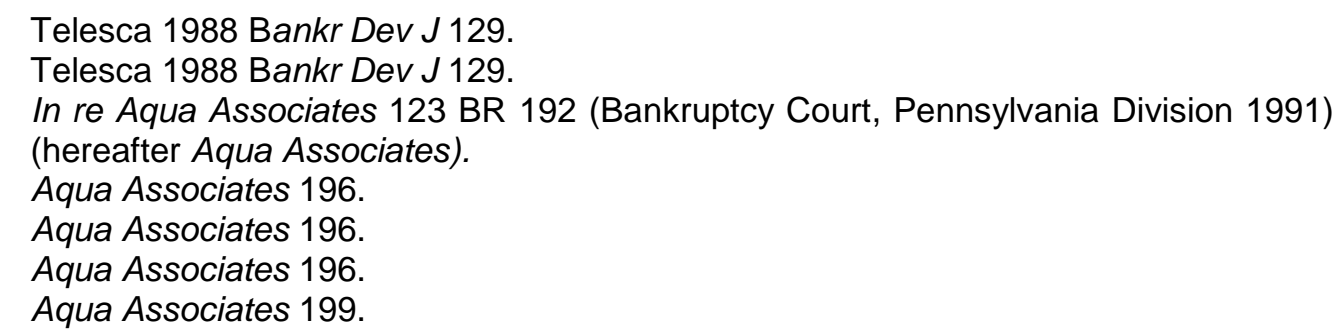


priority) cannot be undone by a subsequent appeal of another creditor. This means that once credit has been approved the decision cannot be reversed (unless the final granting of the application had been stayed pending an appeal). For this reason many creditors face the issue of mootness in contesting an award of section 364 funding on appeal. ${ }^{66}$ Thus necessary protection is given to creditors and there is no danger of priority being denied ex post facto. This also means that if a creditor intends to appeal a successful section 364 application by the debtor, it must obtain a stay of the order pending appeal.

Section 364 can thus be seen to be a carefully crafted section which balances the competing rights and interests of debtors and creditors and ensures viable access to funding. Debtors are supported by the incentivising of post-petition funding and creditors are protected by the requirement of adequate protection. There is also a very necessary procedural mechanism to avoid reversal of a section 364 order after money has already been lent.

\subsection{Cross-collateralisation}

One of the challenges facing post-petition financing in the US is what to do about the problem of cross-collateralisation. This is a means by which a prepetition creditor of the debtor secures its pre- and post-petition loan to the company in Chapter 11 proceedings, using section 364 preference to better its position in the ranking of creditors. The creditor (who is typically unsecured or under-secured with regard to its pre-petition debt) would thus advance further post-petition funds to the debtor company requiring a security interest over all the pre- and post-petition property of that debtor. The catch is that this new security interest would be required to cover the pre-petition debt as well. Thus the fresh finances are secured, typically with super-priority status - and the old finances are given a boost in the ranking of creditors to the same super-priority status.

This type of financing was held to be not authorised by section 364 and to be against the basic priority structure of the code by the Court of Appeal for the Eleventh Circuit in In re Saybrook Manufacturing Co Inc. ${ }^{67}$ This finding was in concordance with the earlier ruling of the Court of Appeal for the Second Circuit in In re Texlon, ${ }^{68}$ which strongly disapproved of crosscollateralisation, but left open the question as to whether it would be

\footnotetext{
66 Compare for example Fontainebleau.

67 In re Saybrook Manufacturing Co Inc 963 F 2d 1490 (Court of Appeal, Eleventh Circuit 1992) 1496.

68 In re Texlon 596 F 2d 1092 (Court of Appeal, Second Circuit 1979) 1098.
} 
disqualified in every conceivable circumstance. The arguments against this practice are set out by Tabb:

- $\quad$ section 364 is supposed to set out the exclusive list of permissible means of financing debtors - cross-collateralisation is not one of them;

- $\quad$ the argument that permitting cross-collateralisation induces creditors to lend money should not be allowed to sway courts into allowing this practice since it is contrary to the principle of equal treatment of similarly situated creditors upon bankruptcy;

- $\quad$ without the protection of Chapter 11 , the advantage given to prepetition debt would constitute a voidable preference;

- $\quad$ considerations of equity were against this practice - the fact that it was fairly common put debtors in the difficult position of choosing between cross-collateralisation and liquidation. This would not occur if the practice were outlawed. ${ }^{69}$

Despite the disapproval of two branches of the Court of Appeal, McCormack notes that many courts still approve this type of financing order. ${ }^{70}$ In re Vanguard Diversified Inc ${ }^{71}$ sets out a four-part test which the debtor must satisfy in order for a court to approve cross-collateralisation:

- the business operations of the debtor will not survive without the proposed financing;

- no alternative finance can be obtained on acceptable terms;

- $\quad$ the proposed lender will not agree to provide finance without crosscollateralisation;

- the proposed financing is in the best interests of the creditor body as a whole. ${ }^{72}$

In Vanguard Diversified cross-collateralisation was permitted by the court. ${ }^{73}$ Indeed at the time of his writing (1986) Tabb noted that cross-

69 Tabb 1986 S Cal L Rev 119-175.

70 McCormack Corporate Rescue Law 191.

71 In re Vanguard Diversified Inc 31 BR 364 (Bankruptcy Court, New York Division 1983) (hereafter Vanguard Diversified).

72 Vanguard Diversified 366.

73 Vanguard Diversified 367. 
collateralisation was becoming a standard term for sophisticated postpetition lenders. ${ }^{74}$

\subsection{The position of employees with regard to post-petition finance}

The US is known for the lack of unionisation of many sectors of its labour force and the relatively weak position in which US labour law leaves employees. ${ }^{75}$ The same is largely true of the treatment of employees under the Bankruptcy Code. Hence employee contracts are "executory contracts" for the purposes of section 365 , which means that the debtor company is free to terminate these employment contracts at will. ${ }^{76}$ Redundant employees are given a preferential claim against the company under section $507(\mathrm{a})(4)(\mathrm{A})$ for wages accruing from up to 180 days prior to Chapter 11 proceedings, but this is limited to $\$ 10000$. Thus it is safe to say that reorganisation often occurs at the expense of the company's workforce and that US law does not protect the plight of redundant employees to any great degree.

The position of workers whose services the company wants to retain is different, however. The company typically extends special treatment to this group in an effort to maintain their loyalty - to the extent that there is a name for this practice - the "Key Employee Retention Plan". ${ }^{77}$ The special treatment typically involves bonuses and other pay-to-stay arrangements. ${ }^{78}$ Thus fresh finance is a very necessary part in maintaining the viability of the company through the retention of essential workers. This is indeed one of the key uses of section 364 finance $^{79}$ and the use of this money in this way needs to be authorised as an expense under section $363 .{ }^{80}$ Retained employees are thus one of the key beneficiaries of post-petition finance, but they certainly do not have any sort of claim on this money outside of the company's good will. Post-petition creditors would definitely have the first bite of the pie should the company go into liquidation, and employees would merely have a preferential claim under section 507 .

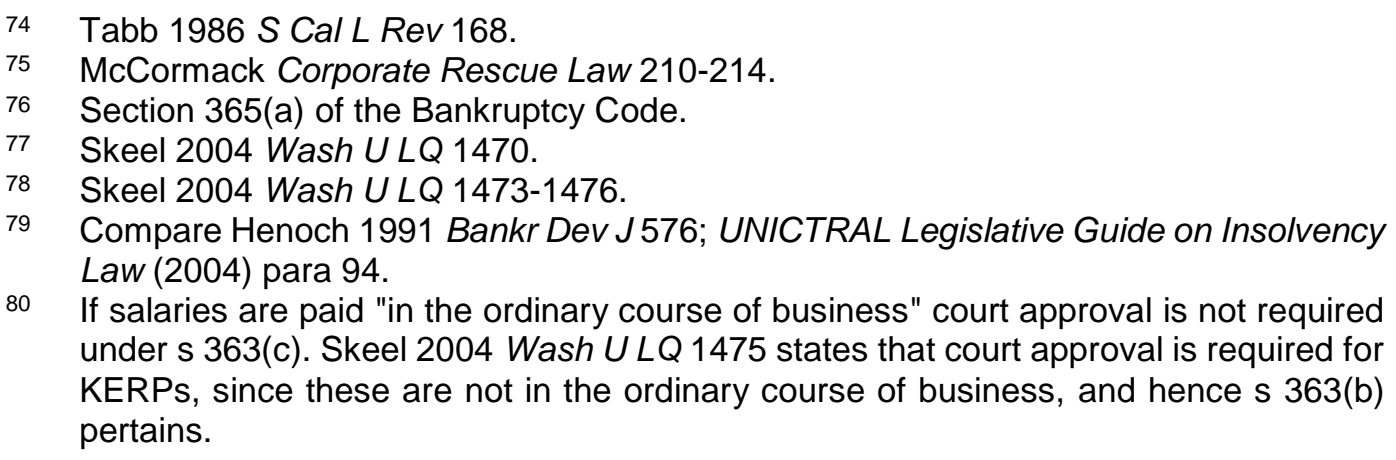

80 If salaries are paid "in the ordinary course of business" court approval is not required under s 363(c). Skeel 2004 Wash U LQ 1475 states that court approval is required for KERPs, since these are not in the ordinary course of business, and hence $s 363(b)$ pertains. 


\title{
2.5 Criticism of Chapter 11
}

This discussion would not be complete without pointing out that Chapter 11 is facing increased scrutiny within the United States itself. As Wessels ${ }^{81}$ notes, it is ironic that while many other countries regard Chapter 11 as a "holy grail", this statutory mechanism is not without criticism at home in the United States. In fact one of the main concerns surrounding the provisions of Chapter 11 is the manner in which it deals with the issue of secured credit. Walters summarises the main objection as follows:

\begin{abstract}
The narrative is now well established and oft-repeated. Whereas in the past, firms filing for chapter 11 would come into the bankruptcy process with at least some unencumbered assets, modern firms tend to have capital structures that are entirely consumed by multiple layers of secured debt. And so, according to the prevailing conventional wisdom, chapter 11, in the general run of cases, has become little more than a glorified nationwide foreclosure process through which secured creditors can exit via a quick section 363 sale or an outright liquidation. ${ }^{82}$
\end{abstract}

In other words, current experience in the United States points to the fact that secured creditors are diverting bankrupt companies away from the Chapter 11 process entirely. ${ }^{83}$ This criticism suggests that some view Chapter 11 simply as an additional foreclosure process, or a debtor-centred form of "unsupervised winding up". 84

\section{Post-commencement finance in South Africa}

\subsection{Sections 134 and 135 of the Companies Act, 2008}

Section 135 of the Act appears in part A ("business rescue proceedings") of Chapter 6, which deals inter alia with various preliminary matters such as entry into business rescue, ${ }^{85}$ the moratorium on proceedings against a company, ${ }^{86}$ the protection of property interests ${ }^{87}$ and the effect of business

81 Wessels 2014 Insolvency Intelligence 5. See further: Bradley and Rosenzweig 1992 Yale LJ 1043; Kirshner 2015 U Penn J Bus L 527.

82 Walters 2015 U III L Rev 545. Also see ABI Symposium 2010 Am Bankr Inst L Rev; Tabb 2013 U III L Rev 103; Tabb 2015 U III L Rev 765.

83 Kirshner 2015 U Penn J Bus L 527 points out that "Increasingly, secured creditors divert bankrupt companies from the traditional Chapter 11 process, which has protected the interests of junior creditors, and push them instead into asset sales under Section 363 of the US Bankruptcy Code".

84 This phrase is borrowed from Rajak and Henning 1999 SALJ 267, who cite the view of Olver Judicial Management 9 . This quote in the original refers to the system of judicial management under the South African Companies Act 46 of 1926. We have appropriated it here for our purposes.

85 Sections $129-131$ of the Act.

86 Section 133 of the Act.

87 Section 134 of the Act. 
rescue on contracts, ${ }^{88}$ employees, ${ }^{89}$ shareholders and directors. ${ }^{90}$ Part A thus deals with certain immediate consequences of business rescue and the inclusion of post-commencement finance in this preliminary section reflects the fact that an injection of fresh capital is likely to be one of the first requirements of a distressed company.

Before considering the substance of section 135, section 134(3) bears mention, as its provisions impact on the position of the existing secured creditor. The section determines that the distressed company may not, during business rescue proceedings, dispose of any property over which another person has any security or title interest unless certain requirements have been complied with. In short, the company will require the prior consent of the affected person, unless the disposal would be sufficient to discharge the indebtedness protected by the affected person's security or title interest, in which case payment out of sale proceeds should promptly be made. ${ }^{91}$

Obtaining fresh finance as such is dealt with in section 135(2):

During its business rescue proceedings, the company may obtain financing ... and any such financing may be secured to the lender by utilising any asset of the company to the extent that it is not otherwise encumbered ....92

A plausible literal reading of this provision would suggest that pre-existing security is not subordinated to new secured lenders. Hence the new finance may be secured only with existing equity in the company's assets or with assets not already subject to a security interest. Post-commencement secured creditors will seemingly rank ahead of unsecured creditors in the order in which such claims are incurred. The immediate question which arises is what if there are no equity or unencumbered assets available to the company in question? Particularly if such a company is indeed in financial distress, it is likely that it will already have pursued all available credit options and have no assets left to secure fresh finance. ${ }^{93}$ The legislation quite simply does not make adequate provision for this scenario. Indeed, the legislative approach taken here stands in stark contrast to that taken by Chapter 11, which, as discussed, offers nuanced mechanisms to

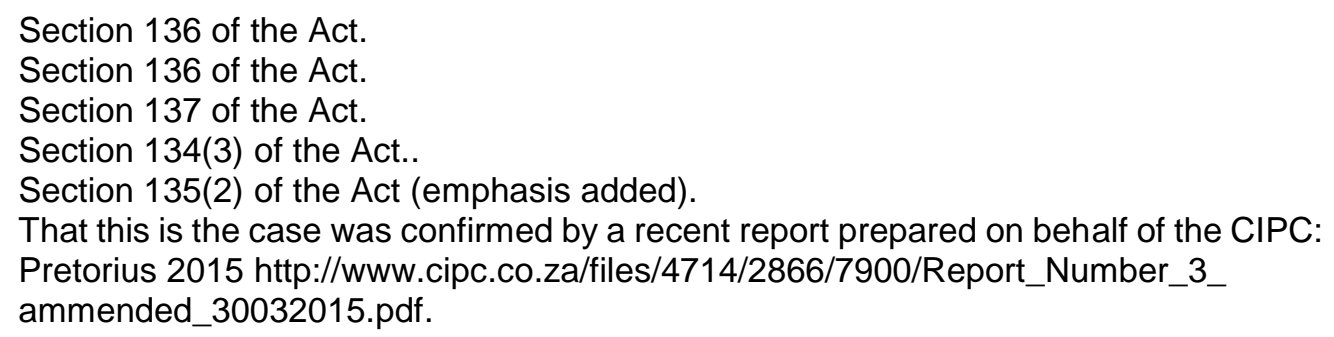


address the likely factual scenario that no equity or unencumbered assets remain available.

The Act also fails to create incentives to attract fresh finance in its ranking of company creditors. This ranking is established by section 135(3) and represents a variation on what would be the conventional liquidation ranking of creditors. The following order of claims is laid down:

- $\quad$ the remuneration of the business rescue practitioner and costs of business rescue proceedings;

- $\quad$ "remuneration, reimbursement for expenses or other amount of money relating to employment" which becomes due and payable by the company to its employees during business rescue;

- $\quad$ secured creditors (including pre-commencement secured creditors), ranked according to the items of property over which the security interest is held and the order in which such security rights were obtained;

- unsecured post-commencement creditors; and

- $\quad$ unsecured pre-commencement creditors.

Section 135(4) holds that this ranking will be maintained if the company should subsequently slide into liquidation (with allowance for the costs of liquidation, of course).

There can hardly be a quibble about prioritising the business rescue practitioner's costs. If there is to be a displacement of a company's management this should be undertaken by a highly competent person and without guarantees of payment this would be difficult to effect. The ranking of employees' claims in second place is ostensibly in line with the Act's general approach, which is more stakeholder friendly. The provisions of section 135(1) seem broad enough to cover wages, reimbursement for expenses, and contributions by the employer to the employees' pension funds. It should be noted, however, that this priority applies only to employment costs incurred during business rescue proceedings. Precommencement employee claims are dealt with separately. ${ }^{94}$ This represents a laudable attempt to ensure that employees are protected, and stands in stark contrast to the harsh American position discussed above.

94 Section 136 of the Act. 
Employees play a pivotal role in ensuring a successful rescue of the business. This stakeholder-inclusive approach also aligns with the increasingly stakeholder friendly perspectives ingrained in the modern approach to corporate governance. ${ }^{95}$

\subsection{Overview of recent decisions by the courts}

In Merchant West Working Capital Solutions (Pty) Ltd $v$ Advanced Technologies and Engineering Company (Pty) Ltd, ${ }^{96} \mathrm{Kgomo} \mathrm{J}$ had the opportunity to consider the ranking of creditors under section 135. The court concluded that this section should be interpreted to mean that claims rank in the following order of preference: first, remuneration and expenses of the practitioner and other persons (including legal and other professionals) for the costs of the business rescue proceedings. Secondly, remuneration for employees that became due and payable post-commencement. Thirdly, the claims of secured lenders for loans or supply made after business rescue commenced (so-called "post-commencement creditors"). Fourthly, unsecured post-commencement creditors; with pre-commencement secured creditors ranked fifth. In sixth place are the remuneration claims of employees, which predate the commencement of business rescue proceedings. Lastly, seventh, are unsecured pre-commencement creditors. ${ }^{97}$ Kgomo J reiterated this interpretation in Redpath Mining South Africa (Pty) Ltd v Marsden. ${ }^{98}$

It is questionable whether this interpretation of the Act is sound. The judgment does not expressly consider the wording of the provision, nor the impact of the chosen interpretation, and in fact does not cite the legislation directly but instead relies exclusively on a single secondary source. ${ }^{99}$ There might be some contention about whether or not secured postcommencement creditors might outrank pre-commencement secured creditors, but it is highly questionable whether the wording of the Act envisages that unsecured post-commencement creditors should also do so.

\footnotetext{
95 See for example IODSA King III 9.

96 Merchant West Working Capital Solutions (Pty) Ltd v Advanced Technologies and Engineering Company (Pty) Ltd 2013 ZAGPJHC 109 (10 May 2013) (hereafter Merchant West).

97 Merchant West para 21.

98 Redpath Mining South Africa (Pty) Ltd v Marsden 2013 ZAGPJHC 148 (14 June 2013) (hereafter Redpath) para 54.

99 Merchant West para 21, where Kgomo J refers to Stein and Everingham New Companies Act 420-421.
} 
The constitutional era has seen a break with South Africa's literalist past when it comes to statutory interpretation. ${ }^{100}$ The Constitutional Court has often discussed statutory interpretation, stressing a contextual, purposive approach, which interprets a statute through the "prism of the Bill of Rights". ${ }^{101}$ Even in the dry world of commercial law, the Supreme Court of Appeal has confirmed that the proper approach to statutory (and other textual) interpretation is a purposive one, which examines context from the outset, without needing the open sesame of ambiguity or absurdity. ${ }^{102}$ Wallis JA held as follows in Natal Joint Municipal Pension Fund:

\begin{abstract}
Interpretation is the process of attributing meaning to the words used in a document, be it legislation, some other statutory instrument, or contract, having regard to the context provided by reading the particular provision or provisions in the light of the document as a whole and the circumstances attendant upon its coming into existence. ${ }^{103}$
\end{abstract}

Wallis JA went on to explain that this approach requires an interpreter to consider the language used in a provision in the light of the ordinary rules of grammar and syntax, and to balance this with the apparent purpose of a provision and its context, which includes the material known to those who drafted it. ${ }^{104}$ This process is objective, not subjective, requiring an investigation into the meaning of the words actually used. ${ }^{105} \mathrm{~A}$ court should also prefer a meaning which makes business common sense, in line with purposive construction. ${ }^{106}$ Finally, judges should be careful not to diverge from interpretation into legislation: any meaning derived from a text must be grounded in the language thereof. ${ }^{107}$

It is not clear how Kgomo J's interpretation of the post-commencement finance provisions accords with this approach. In spite of the fact that interpretation is now considered a unitary process, ${ }^{108}$ the literal meaning of the words must remain the starting point of any engagement with the text.

100 Section 39(2) of the Constitution of the Republic of South Africa, 1996. See generally Investigating Directorate: Serious Economic Offences $v$ Hyundai Motor Distributors (Pty) Ltd. In re: Hyundai Motor Distributors (Pty) Ltd v Smit 20011 SA 545 (CC) (hereafter Hyundai) paras 21-26.

101 Hyundai para 21.

102 Natal Joint Municipal Pension Fund v Endumeni Municipality 20124 SA 593 (SCA) (hereafter Natal Joint Municipal Pension Fund) para 18. See further: Bothma-Batho Transport (Edms) Bpk v S Bothma \& Seun Transport (Edms) Bpk 20142 SA 494 (SCA) (hereafter Bothma-Batho) paras 10-12; Wallis 2010 SALJ.

103 Natal Joint Municipal Pension Fund para 18.

104 Natal Joint Municipal Pension Fund para 18.

105 Natal Joint Municipal Pension Fund para 18.

106 Natal Joint Municipal Pension Fund para 18.

107 Natal Joint Municipal Pension Fund para 18.

108 Bothma-Batho para 12. 
Certainly the ideal is a comprehensive approach based on the actual wording of the document, as opposed to one that takes only the context into account. Subsection 135(3) gives post-commencement creditors (whether secured or not) a ranking above that of "all unsecured claims against the company". ${ }^{109}$ The express inclusion of unsecured claims surely points by implication to the exclusion of secured claims in this instance. ${ }^{110}$ Such an interpretation also aligns with section 135(2), in terms of which assets may be utilised for the purposes of security post-commencement only to the extent that they are unencumbered. The interpretation taken by the court effectively undermines or renders obsolete the provisions of this subsection by negating the rights of the pre-commencement secured creditor almost entirely. Therefore the consequences of the interpretation will likely not pass constitutional muster as the argument could convincingly be made that such an interpretation of the legislation will deprive pre-commencement secured creditors of their property rights in an unconstitutional manner. ${ }^{111}$

Delport further argues that the decision taken in Merchant West does not seem to be in accordance with section 135(3) because the subsection does not refer to secured claims before business rescue began, as these are regulated by section $134 .{ }^{112}$ The author points out that although the same ranking was also used in Redpath Mining the Court in that instance expressly referred to the rights of "secured" creditors as contained in section 134(3). ${ }^{113}$ In the light of this it bears mention that section 134 deals with precommencement secured creditors in instances where the company aims to dispose of an encumbered asset. It seems not to extend to instances where the company seeks to further encumber such an asset. As such it is submitted that section 135(3)(b) might well apply in addition to section 134 to govern such instances. If so, it is lamentable that the Legislature does not expressly set out how this would affect the ranking. The fact that section 135(2) allows for assets to be further encumbered only to the extent possible, and then determines that such creditors have a preference "in the order in which they were incurred", 114 seems to suggest that what was envisaged was a ranking that preferred the secured pre-commencement

\footnotetext{
109 Section 135(3)(b) of the Act.

110 This is the so-called expressio unius est exclusio alterius rule. For a modern discussion, see Masetlha v President of the Republic of South Africa 20081 BCLR 1 (CC) para 192.

111 A comprehensive discussion of matters related to the constitutionality of the court's approach falls outside of the scope of this paper but would of course be based on the rights contained in s 25 of the Constitution of the Republic of South Africa, 1996.

112 Delport "Post-commencement Finance" 480(42).

113 Delport "Post-commencement Finance" 480(42).

114 Section $135(3)(b)$ of the Act.
} 
creditor, followed by secured post-commencement creditors in the order in which their claims were incurred. This interpretation has the added benefit of giving meaning to the provisions of subsection 135(2).

Pretorius and Du Preez observe that the rankings as set out in the Act prefer the post-commencement secured creditor, but the authors subsequently support the interpretation of the court in Merchant West as "an encouraging development for the distressed investing industry". ${ }^{115}$ The authors do not engage with the logic of the court and it is not clear how their argument can be justified. To be sure, mechanisms to support the distressed investing industry (to use the authors' term) should be forthcoming and, as argued above, the legislation in its current form seems to be inadequate. However, as will be argued in the conclusion below, the solution does not lie in disregarding the clear wording of the Act in favour of an interpretation that ostensibly addresses the concerns created by the Legislature's apparent omissions. It is especially ill conceived to attempt to incorporate mechanisms which are accompanied by extensive judicial oversight elsewhere without also including the necessary safeguards and scrutiny. In spite of the controversy, it seems as though the observations related to the ranking of creditors in both of Kgomo J's decisions above remain obiter dicta and will hence not bind future courts. ${ }^{116}$

Post-commencement finance was also considered in the matter of Kritzinger $v$ Standard Bank of South Africa Ltd. ${ }^{117}$ In Kritzinger the applicant company, which was in the business of providing mining supplies, found itself in financial distress. It had been a client of the respondent bank for the preceding nine years, and held two accounts with it - one an overdraft facility with a R800 000 limit, the other a salary account used to pay employees and for certain other business expenses. ${ }^{118}$ Nine years before the events in question the applicant company had ceded book debts to the respondent bank. ${ }^{119}$ After being notified of the initiation of business rescue proceedings, the bank set off funds in the salary account against the deficit in the overdraft facility and demanded that the book debts be paid directly

115 Pretorius and Du Preez 2013 SA J Entrep \& Small Bus Man 171. This article offers a comprehensive analysis of the state of post-commencement finance in South Africa.

$116 \mathrm{Kgomo} \mathrm{J}$ 's observations regarding the ranking of creditors form part of a general overview of the consequences of business rescue and do not form part of the ultimate decision. See Merchant West para 52; Redpath paras 29-39.

117 Kritzinger $v$ Standard Bank of South Africa Ltd 2013 ZAFSHC 215 (19 September 2013) (hereafter Kritzinger).

118 Kritzinger para 10.

119 Kritzinger para 23. 
to it. ${ }^{120}$ Upon receiving this instruction, the business rescue practitioner opened an account with another financial services provider (Investec) and started receiving book debts in the new account. ${ }^{121}$ The overdraft agreement with Standard Bank contained a clause that entitled that bank to revoke this facility at any time, should the financial position of the applicant deteriorate. ${ }^{122}$ In the light of this provision, Rampai AJP concluded that the actions of the respondent bank had been justified. ${ }^{123}$ By notifying the bank of the commencement of business rescue proceedings the company itself admitted financial distress, and the bank as final arbitrator had the sole and final discretion to determine that the financial position of the applicant had deteriorated and to cancel the overdraft agreement. ${ }^{124}$

The court confirmed that the respondent bank had merely exercised its contractual powers in a lawful and acceptable manner in terms of the recognised hierarchy of creditors. In this regard the court made the following noteworthy observation:

\footnotetext{
The respondent is still a secured creditor post commencement of business rescue proceedings in much the same way as it was prior to the commencement of such proceedings. The commencement of such proceedings did not and could not demote the respondent from its rightful position as a creditor with a secured rank. ${ }^{125}$
}

These sentiments seem to contradict in strong terms the conclusion reached by the court in the Merchant West and Redpath decisions and instead align with the protection afforded to secured creditors under section 134 of the Act (as set out above). The court came to the conclusion that the provisions of section 133(1) of the Act (on which the applicant had relied) did not preclude the bank from applying set-off, given the facts of the case. Rampai AJP argued further that even if this were not the case, it would be inequitable to order the respondent bank to reverse the set-off transaction in the light of the facts both that its security had been "drastically diminished if not completely eroded", and that such a reversal would release the affected funds to the parties whose "subversive conduct" had rendered the applicant's security for repayment of the overdraft facilities meaningless. ${ }^{126}$ In the words of the judge, "this the law could not countermine". ${ }^{127}$ In relation

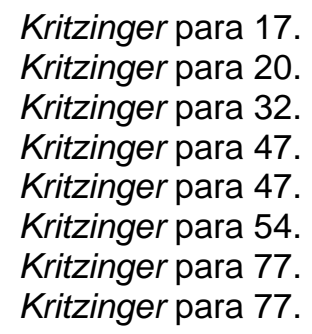


to the payment of the book debts into the new Investec account, the court found that the first applicant (the business rescue practitioner) had contravened s 134(3), which protects the rights of the secured precommencement creditor. ${ }^{128}$

\subsection{Cross-collateralisation under section 135?}

If there is a lack of incentive for creditors to invest in reorganising companies in South Africa, perhaps some sort of cross-collateralisation goal could motivate a lender to further secure its position with regard to a company's assets. Cross-collateralisation (as stated above) is when postcommencement finance is granted to a debtor on the agreement that this will constitute a secured loan, with the security extending to the precommencement debt as well. This could be achieved in South Africa by taking security in all unencumbered property of the debtor to the extent that such property exceeds the value of the post-commencement loan. Would this practice be permitted under the new business rescue laws? The wording of section 135(2) does not condone or disallow this practice, speaking only of security for present financing ("any such financing may be secured to the lender" - see the discussion in part 3.1 above). Ultimately, this is a policy-laden question for a court interpreting the provision to determine.

\section{$4 \quad$ Analysis}

\subsection{The Supreme Court of Appeal decision in Kariba}

The decision in Kariba centered on an interpretation of the term "binding offer" found in section 153(1)(b)(ii) of the Act and thus does not directly pertain to the issue of post-commencement financing. ${ }^{129}$ The court was specifically called on to determine whether a "binding offer" made in terms of the section implied a mandatory acceptance of such an offer by the offeree. ${ }^{130}$ The court a quo had concluded that such an offer should indeed be considered binding in this way and based its decision on what was considered a similar procedure contained in Chapter $11 .{ }^{131}$ The relevance

\footnotetext{
128 Kritzinger para 51.

129 Section 153(1)(b)(ii) of the Act provides that (if a business rescue plan has been rejected) "any affected person, or combination of affected persons, may make a binding offer to purchase the voting interests of one or more persons who opposed the adoption of the business rescue plan, at a value independently and expertly determined, on the request of the practitioner, to be a fair and reasonable estimate of the return to that person, or those persons, if the company were to be liquidated".

130 Kariba paras 12-21.

131 Kariba para 8.
} 
of the decision for our present purposes, however, lies in the Supreme Court of Appeal's observations on the appropriateness of using the Chapter 11 procedure as an interpretative guide to the particular section of the Act in question. In this regard, Dambuza AJA points out that:

[C]ertain factors distinguish the process as provided for in our Act from the procedure provided for in the U.S. Bankruptcy Code. First, under the U.S. Bankruptcy Code it is the court that makes the decision as to whether rejection of a business plan by a creditor should be ignored. Obviously that decision would be taken after due consideration of all relevant factors. In $s$ 1129(a) of the U.S. Bankruptcy Code the requirements that must be satisfied before a court can confirm a rescue plan are listed. And the provisions of this section are peremptory. ${ }^{132}$

The accepted meaning of term "offer" as it has developed in South African jurisprudence was also analysed and the court concluded that the Legislature intended for the offer in question to be binding on the offeror (an interpretation which aligns with the position at common law). ${ }^{133}$ No further mention was made of Chapter 11 or its worth as persuasive authority when interpreting the Act. The SCA did, however, highlight the untenable practical consequences of an interpretation that aligned with Chapter 11 as argued for by counsel for the respondent debtor company. ${ }^{134}$ These practical examples make it abundantly clear that such a construal effectively plucks a provision from United States law in a vacuum - leaving behind the contextual safeguards, such as oversight mechanisms, that anchor and give meaning to its terms. It is thus not only in interpreting legislation, but also in drafting it, that one runs the risk of disregarding such context when transplanting legal provisions from elsewhere.

\subsection{Legal transplants ${ }^{135}$}

Legal transplantation ${ }^{136}$ is almost as old as the law itself. ${ }^{137}$ However, in a modern and globalised society many countries are subsuming the laws of other jurisdictions at an ever-increasing pace - a trend motivated by

\footnotetext{
132 Kariba para 16.

133 Kariba paras 17-19.

134 Kariba paras 22-24.

135 There is a vast literature dedicated to the phenomenon of legal transplants. See for example Watson Legal Transplants; Kahn-Freund 1974 MLR; Legrand 1997 MJECL; Berkowitz, Pistor and Richard 2003 Am J Comp L; Miller 2003 Am J Comp L; Markovits 2005 Cornell Int'I LJ; Graziadei 2009 Theo Inq L.

136 Watson Legal Transplants 21 defines legal transplantation as "the moving of a rule or a system of law from one country to another, or from one people to another".

137 Miller $2003 \mathrm{Am}$ J Comp L 839. Miller gives the (1 $7^{\text {th }}$ century BC) Code of Hammurabi as one of the oldest examples.
} 
necessity, political pressure, ${ }^{138}$ expediency or otherwise. ${ }^{139}$ Miller ${ }^{140}$ rightly points out:

\begin{abstract}
Whether it is in order to assimilate or diverge from the value and necessity of legal transplants and the concomitant need to take heed of jurisprudence developed in other jurisdictions when interpreting alien precepts can hardly be called into question.
\end{abstract}

Most countries will find themselves unable to attract international investment or engage in international trade without at least to some extent aligning their legislation with international norms and best practices. ${ }^{141}$ Scholars are in two camps where legal transplants are concerned.

On the one hand, proponents of legal transplant theory (for example, and most famously, Watson) argue that there are few social challenges to lifting rules or systems of law from one jurisdiction to the next. ${ }^{142}$ This is due to the fact that the law is considered socially neutral and can be divorced from socio-economic, political and historical context. ${ }^{143}$ Of greater significance, it could be argued, would be the legal tradition from which the rule stems and this should be taken into account when considering the likelihood of a successful transplant. ${ }^{144}$ The transplant theory was explained and advanced by Cotterrell, and drew distinctions between law that is culturally based and law that is instrumental. ${ }^{145}$ As such, areas such as family law and the law of succession are considered culturally based, and will be more susceptible to influences of cultural and social context, whereas corporate law is in general considered instrumental and therefore more neutral and better suited to becoming the subject of a transplant. ${ }^{146}$ Corporate law, Cotterrell argues, relies on "economic interests rather than national customs or sentiments" and therefore it is less likely that new rules or systems will be rejected following the transplant. ${ }^{147}$

On the other hand, contextualist theory opposes this notion. As KahnFreund ${ }^{148}$ points out:

\footnotetext{
138 See for example Gillman 2009 Geo J Int'l L 263.

139 An example is the relatively recent legal transformation that took place on a grand scale in Eastern European countries, see Mistelis 2000 Int'l Law 1055.

140 Miller 2003 Am J Comp L 839.

141 Miller 2003 Am J Comp L 839.

142 Watson 1976 LQR 79.

143 For a summary of the discourse, see Cabrelli and Siems 2015 Am J Comp L 124.

144 Cabrelli and Siems 2015 Am J Comp L 124.

145 Cotterrell Law, Culture and Society 118.

146 Cotterrell Law, Culture and Society 118.

147 Cotterrell Law, Culture and Society 126; Cabrelli and Siems 2015 Am J Comp L 124.

148 Kahn-Freund 1974 MLR 27. See also and in general Legrand 1997 MJECL 114.
} 
[A]ny attempt to use a pattern of law outside the environment of its original country entails a risk of rejection ... [and] its use requires a knowledge not only of the foreign law but also of its social and above all political contexts.

Similarly culturalist theory completely rejects the idea that legal transplants are at all possible. In the words of Legrand, "[i]n any meaningful sense of the term, 'legal transplants'... cannot happen". ${ }^{149}$ This is because of the fact that any rule which is assimilated is in fact also culturally appropriated to the extent that it becomes inappropriate to refer to it as a transplant at all. ${ }^{150}$

A middle road may exist between these camps: Friedman argues that it is modernity itself that makes it possible for vastly dissimilar systems to assimilate, due to the fact that developing economies will increasingly face the same challenges that developed countries have been grappling with for years, thus prompting a need for legal transplants to occur. ${ }^{151}$

Further analysis of the phenomenon of legal transplants beyond this brief introduction falls outside of the scope of this paper. Suffice it to say that transplants remain a reality in modern legal discourse and that it is an undeniable fact that jurisdictions the world over, and particularly in the developing world, are increasingly driven to conform their systems of law under international pressure to what is considered best practice. ${ }^{152}$ Corporate legislation anecdotally has the most to gain from such alignments and indeed ensuring that our legislation remains in step with international developments was one of the drivers behind the draft 2008 legislative reforms. ${ }^{153}$ In addition to the usual caveats that apply when transplanting law, Loubser points to a number of reasons why, popular as it may be, Chapter 11 could be a Trojan horse as far as the law of insolvency and corporate reorganisation is concerned: ${ }^{154}$

An insolvency system should arise out of existing cultural conditions and attitudes, and how debt is viewed in a specific country. Transplanted insolvency laws do not reflect these views and are then expected to change the cultural attitude to debt and debt forgiveness, something they cannot do, and so these imported systems are often ineffective. ${ }^{155}$

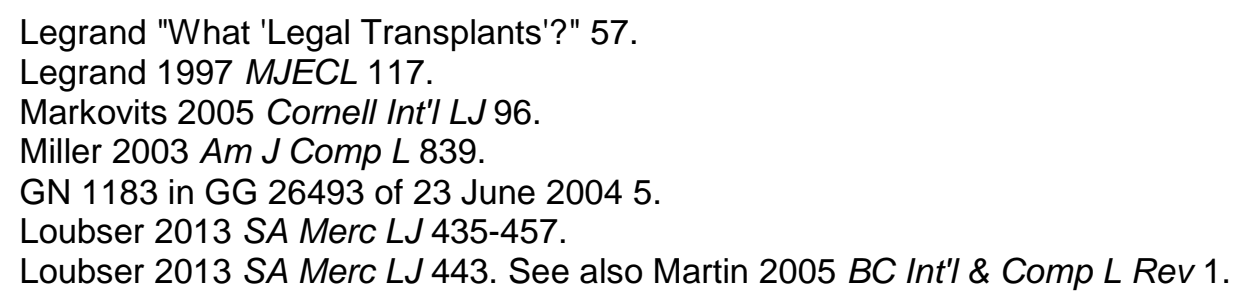


There is academic argument to the effect that Americans view insolvency with a spirit of optimism that other countries do not share. Such scholars would hold that being declared insolvent does not bring with it the usual stigma and judgements, and that the rehabilitation of the debtor to his erstwhile state of being a contributing consumer has high priority. ${ }^{156}$ As Martin ${ }^{157}$ points out:

The United States never adopted the English's unforgiving and highly administrative bankruptcy process... The focus in the United States instead was on balancing the desires of creditor groups and debtor groups, and promoting commerce. To this day, a United States bankruptcy debtor's freedom of choice about whether to liquidate or reorganize remains a key component of United States bankruptcy law... While in most parts of the world business failure causes less stigma than personal financial failure, both forms are viewed far more negatively in England, Australia, and Canada than in the United States.

The fact that this societal norm extends to corporate reorganisation is evidenced by the eager participation of financial service providers incentivised to invest in financially distressed firms. Indeed McCormack goes so far as to describe the United States' DIP financing regime as a "prime candidate" for "banks looking for a low-risk, high yield venture". ${ }^{158}$ Chemical Bank, for example, a United States company which established a specialist DIP unit in 1984, claimed after a considerable lapse of time that it had "never lost a penny" in this type of venture. ${ }^{159}$ In addition, in the United States a number of debtor-centred features of insolvency and bankruptcy laws "are structured to correct slack and improve managerial decision making" and are in fact thus considered by some to be "last-resort governance mechanisms". ${ }^{160}$ This is not the position in South Africa, which has traditionally taken a creditor-friendly stance and where, if anything, a debtor-centred approach is viewed with scepticism. ${ }^{161}$

\subsection{Further observations}

The inclusion of a post-commencement financing provision in the new South African Companies Act is a necessary step in favour of successful reorganisation. Finance is essential to pay employees, maintain supplies of goods and services, and provide for the miscellaneous overhead costs

\footnotetext{
156 Richardson, Gallagher and Szekely 2008 JIBFL 457; Rochelle 1996 TSAR 316; Martin 2005 BC Int'l \& Comp $L \operatorname{Rev} 3$, 22. For a comprehensive overview of the history of American insolvency law, see Tabb 1995 Am Bankr Inst L Rev 5.

157 Martin 2003 Am Bankr Inst L Rev 367-368.

158 McCormack Corporate Rescue Law 178.

159 McCormack Corporate Rescue Law; Henoch 1991 Bankr Dev J 581.

160 Triantis 1997 NY Sch J Int'/ \& Comp L 196.

161 Burdette 2004 SA Merc LJ 244.
} 
necessary for the business to continue as a functioning entity. ${ }^{162}$ It is not difficult to establish that there is a demand for post-commencement finance, but what are the incentives for lenders? Clearly it is potentially risky to lend to a corporation which is by definition in financial distress and hence the legislative safeguards which must be put in place to protect new and existing creditors. In the United States incentives for new lending are created by priority over pre-petition unsecured creditors or even by super-priority over pre-petition secured creditors under section 364(d). At the same time, section 364 ensures that pre-petition creditors are adequately protected. While the ranking of creditors might be altered, courts are careful not to undermine the legitimate interests of pre-petition secured creditors. This protection is said to stem from a constitutional protection of property rights. ${ }^{163}$

Similar considerations appear to have moved the South African Legislature, so that security for post-commencement finance may be granted only to the extent that assets "are not otherwise encumbered". ${ }^{164}$ Section 135 of the Act is much simpler and far less flexible than its United States counterpart, however. In particular, the failure to allow for any form of super-priority for post-commencement secured creditors suggests that the South African Legislature has omitted the crucial feature of a loan incentive to prospective creditors particularly in instances where a distressed debtor has no unencumbered assets left. The United States requirement of adequate protection and the strict enforcement thereof in the courts shows that superpriority need not spell the end for pre-commencement creditors. The consequences of the decisions in Redpath and Merchant West is that this interpretation in effect now allows for a super-priority to be afforded to a post-commencement creditor without any of the protection and court oversight that accompanies this procedure in terms of Chapter 11. It also seems to be completely at odds with the provisions of section 134. Indeed, the pre-commencement secured creditor is left in a perilous position. Ironically this might well be a strategy that companies in business rescue could abuse, since this mechanism could be used to leverage a precommencement creditor into providing further funds in order to allow that creditor to make use of cross-collateralisation to improve its position or merely to avoid being usurped by another creditor.

\footnotetext{
162 For an overview of the significance of post-commencement finance in business rescue, see Pretorius and Du Preez 2013 SA J Entrep \& Small Bus Man.

163 See part 2.2 above.

164 Section 135(2) of the Act.
} 
Five years have passed since the Act came into operation. It would seem there is already evidence indicating that one of the critical challenges facing companies under business rescue is the fact that post-commencement finance is not forthcoming in South Africa. In a report prepared on behalf of the Companies and Intellectual Property Commission (CIPC), Pretorius highlights concerns that have come to light. ${ }^{165}$ Pretorius ${ }^{166}$ points out that South Africa appears to have a very small venture capital market. Furthermore, he notes that:

\begin{abstract}
The perceived "low preference" that a PCF investor will hold in case of an eventual liquidation (if rescue fails) also contributes to the adversity to PCF provision. Related to the lack of data integrity, potential PCF providers perceive the risk as too high for the allocated preference.
\end{abstract}

The report further confirms that, as is the case in the United States, most of an embattled company's assets are already encumbered by the time that the company files for business rescue and it would appear that alternative advanced financing options are under-utilised (the report refers specifically to mechanisms such as debt swaps or buying the bank's debt). ${ }^{167}$ In the light of the fact that business rescue practitioners consider it an unwritten rule that a lack of post-commencement finance means that there is there is little prospect of a successful rescue, a lack of comprehensive legislative regulation may well prove fatal. ${ }^{168}$

\title{
5 Conclusion
}

It is abundantly clear that in spite of a purported reliance by the South African Legislature on Chapter 11 of the United States Bankruptcy Code, the distinctions between the Act's business rescue provisions and their American counterpart are stark - at least as far as post-commencement finance is concerned. Perhaps the most noteworthy of these distinctions is the lesser degree of court oversight in the South African process. As the decision in Kariba shows, this is the case for many of Chapter 6's provisions. The impact of this must not be underestimated and the courts should

\footnotetext{
165 Pretorius 2015 http://www.cipc.co.za/files/4714/2866/7900/Report_Number_3_ ammended_30032015.pdf.

166 Pretorius 2015 http://www.cipc.co.za/files/4714/2866/7900/Report_Number_3 ammended_30032015.pdf 46.

167 Pretorius 2015 http://www.cipc.co.za/files/4714/2866/7900/Report_Number_3_ ammended_30032015.pdf 48.

168 Pretorius 2015 http://www.cipc.co.za/files/4714/2866/7900/Report_Number_3 ammended_30032015.pdf 46.
} 
proceed with great caution when drawing comparative conclusions from Chapter 11 and related American cases.

This paper's proposed solution is not that the provisions of Chapter 11 should be transplanted in their entirety through an amendment of the Act to align with its United States counterpart. The Chapter 11 procedure is not necessarily the most suitable solution for South Africa and in any event, recent reports would suggest that reorganization is a fallible process in both jurisdictions, and the United States is itself reconsidering various aspects of Chapter $11 .{ }^{169}$ One of the core problems that South Africa would face if it tried to more fully replicate the United States' post-commencement financing provisions is that these rely extensively on court oversight. In South Africa, by contrast, court oversight is shunned, due to the perception that undue court involvement will encumber business rescue proceedings, rendering it costly and time consuming. ${ }^{170}$

There is some irony in this reasoning if one considers the myriad of factual variations that might present themselves in this type of scenario, as well as the number of stakeholders with conflicting interests and the nuanced manner in which such a matter must surely be managed in the interests of both commercial realities and legal certainty. The fact that the South African Legislature did not provide for a more rigorous and detailed regulatory regime with regard to post-commencement finance might actually represent as big a threat to corporate reorganisation as unwarranted court oversight. The current position might also have the unexpected consequence that court oversight occurs by default, when creditors without statutory recourse to this form of supervision are forced to turn to litigation in a situation where the lacunae in the Act are abused. ${ }^{171}$

There may, however, be other options for oversight that could prove as effective as the United States' mechanism, while still minimising delay and legal costs. For example, it might be possible to give the Companies Tribunal jurisdiction to oversee applications by creditors for priority in instances where there are no unencumbered assets left, yet adequate protection of the interests of all remaining creditors can be established. For

169 South Africa: Pretorius 2015 http://www.cipc.co.za/files/4714/2866/7900/Report_ Number_3_ammended_30032015.pdf; United States: ABI date unknown https://abiworld.app.box.com/s/vvircv5xv83aavl4dp4h.

170 Burdette 2004 SA Merc LJ 410; Rajak and Henning 1999 SALJ 276.

171 See for example Kariba and Kritzinger discussed above. See further: ABSA Bank Limited v Newcity Group (Pty) Ltd 20133 All SA 146 (GSJ), where a final liquidation order was refused and the business rescue provisions upheld instead, in spite of the debtor company's admitting that this was effectively an abuse of process. 
factual examples where this might be appropriate, the reader is referred to the American cases discussed above in Part Two. The Act already makes provision for similar forms of extra-judicial oversight in other contexts such as the jurisdiction of the Takeover Regulations Panel to oversee so-called "affected transactions" involving "regulated companies". ${ }^{172}$ Similarly, it would be possible to regulate certain types of company more keenly than others. There are, of course, several other examples of this type of differentiation in the Act. ${ }^{173}$ In fact, in the context of Chapter 6 the regulations already make provision for a process of differentiation for the purposes of the appointment of the business rescue practitioner. ${ }^{174}$ This could be taken into account to address concerns that smaller entities might be affected more detrimentally by the costs of court oversight than larger ones.

After analysing the existing jurisprudence related to Chapter 6, Osode ${ }^{175}$ argues that the South African case law is beginning to demonstrate the "gaps in the framework" of our business rescue provisions, reflecting poor quality drafting. The fact that South African courts are faced with factual scenarios for which the Act makes no provision could lead to a forced interpretation of its provisions. The danger exists that an interpretation such as the one in Merchant West is favoured by later courts as a robust probusiness rescue position. This type of reasoning equates more aggressive protection of post-commencement creditors with being pro-business rescue, whereas a more restrained approach is by default seen as being pro-liquidation and more creditor friendly. Theoretically more robust rescue incentives and adequate protection for post-commencement financiers will bolster business rescue efforts. Attempting to achieve this end by reading United States-type mechanisms into the provisions of the existing Act, as was done by the court a quo in Kariba, as well as in Merchant West and Redpath, would be misguided, however. In fact, such a trend could, without the necessary and concomitant foreign safeguards, paradoxically threaten the viability of business rescue in South Africa, given the fact that the success of these provisions relies to a great extent on the trust of stakeholders, especially creditors. ${ }^{176}$

\footnotetext{
172 See ch 5 of the Act.

173 For example the "public interest score" introduced by $s 30(7)$, or the definition of "regulated company" in $\mathrm{s} 117$ of the Act.

174 Regulation 127(2)(b) under the Act differentiates between "large", "medium" and "small" companies.

175 Osode 2015 Penn State J L Int'l Affairs 488.

176 Rajak and Henning 1999 SALJ 287.
} 
Chapter 11 ostensibly favours reorganisation and the skepticism that the process is met with elsewhere is far less of a hindrance in the United States. ${ }^{177}$ While the South African Act supports reorganization by making provision for post-commencement financing (this is not true, for example, of the United Kingdom) $)^{178}$ the balance struck in section 135, the lack of nuance, and the complete lack of court oversight make it impossible to protect pre-commencement secured creditors while at the same time offering viable options to persuade post-commencement creditors to invest in a company in distress. This is certainly one of the areas of the Act that the Legislature should revisit to seek a creative and realistic solution. As this analysis has shown, interpretation by the courts will not be able to save the existing provisions that regulate post-commencement financing.

\section{Bibliography}

\section{Literature}

ABI Symposium 2010 Am Bankr Inst L Rev

American Bankruptcy Institute Symposium "Chapter 11 at the Crossroads: Does Reorganization Need Reform? - A Symposium on the Past, Present and Future of US Corporate Restructuring" 2010 Am Bankr Inst L Rev 365404

Armour, Cheffins and Skeel 2002 Vand $L$ Rev

Armour J, Cheffins BR and Skeel DA "Corporate Ownership Structure and the Evolution of Bankruptcy Law: Lessons from the United Kingdom" 2002 Vand L Rev 1699-1785

Berkowitz, Pistor and Richard 2003 Am J Comp L

Berkowitz D, Pistor K and Richard JF "The Transplant Effect" 2003 Am J Comp L 163-203

Bradley and Rosenzweig 1992 Yale LJ

Bradley M and Rosenzweig M "The Untenable Case for Chapter 11" 1992 101 Yale LJ 1043-1089

Bradstreet 2011 SALJ

Bradstreet R "The New Business Rescue: Will Creditors Sink or Swim?" 2011 SALJ 352-380

177 See Moss 1997-1998 Brook J Int'l L 115 for a comparison of US and UK law in this regard.

McCormack Corporate Rescue Law 176. 
Broude 1983-1984 Business Lawyer

Broude RF "Cramdown and Chapter 11 of the Bankruptcy Code: The Settlement Imperative" 1983-1984 Business Lawyer 441-454

Burdette 2004 SA Merc LJ

Burdette D "Some Initial Thoughts on the Development of a Modern and Effective Business Rescue Model for South Africa (Part 1)" 2004 SA Merc LJ 244-263

Cabrelli and Siems 2015 Am J Comp L

Cabrelli D and Siems M "Convergence, Legal Origins, in Comparative Corporate Law: A Case Based and Quantitative Analysis" 2015 Am J Comp L 109-153

Cassim et al Contemporary Company Law

Cassim FHI et al Contemporary Company Law $2^{\text {nd }}$ ed (Juta Cape Town 2012)

Cotterrell Law, Culture and Society

Cotterrell R Law, Culture and Society: Legal Ideas in the Mirror of Social Theory (Ashgate Aldershot 2006)

Delport "Post-commencement Finance"

Delport P "Post-commencement Finance" in Delport P et al Henochsberg on the Companies Act 71 of 2008 (LexisNexis Durban 2011) Vol 1: 480(42)(45)

Emmerman 2015 Am Bankr Inst J

Emmerman $\mathrm{K}$ "Reorganizing and Restructuring Insolvent Companies in Germany: A Move towards Chapter 11" 2015 Am Bankr Inst J 26-28

Friedman 1992-1993 Cardozo L Rev

Friedman $\mathrm{J}$ "What Courts do to Secured Creditors in Chapter 11 Cram Down" 1992-1993 Cardozo L Rev 1495-1544

Gillman 2009 Geo J Int'/ L

Gillman E "Legal Transplants in Trade and Investment Agreements: Understanding the Exportation of US Law to Latin America" 2009 Geo J Int'I L 263-301

Graziadei 2009 Theo Inq L

Graziadei M "Legal Transplants and the Frontiers of Legal Knowledge" 2009 Theo Inq L 723-744 
Henoch 1991 Bankr Dev J

Henoch BA "Postpetition Financing: Is There Life After Debt?" 1991 Bankr Dev J 575-604

IODSA King III

Institute of Directors of Southern Africa King Report on Corporate Governance for South Africa (IODSA Sandton 2009)

Kahn-Freund 1974 MLR

Kahn-Freund O "On Uses and Misuses of Comparative Law" 1974 MLR 127

Kirshner 2015 U Penn J Bus L

Kirshner JA "Design Flaws in the Bankruptcy Regime: Lessons from the UK for Preventing a Resurgent Creditors' Race in the US" 2015 U Penn J Bus L 527-571

Legrand 1997 MJECL

Legrand P "The Impossibility of 'Legal Transplants'" 1997 MJECL 111-124

Legrand "What 'Legal Transplants'?"

Legrand P "What 'Legal Transplants'?" in Nelken D and Feest $\mathrm{J}$ (eds) Adapting Legal Cultures (Hart Oxford 2001) 55-69

LoPucki and Triantis "Systems Approach"

LoPucki LM and Triantis GG "A Systems Approach to Comparing US and Canadian Reorganisation of Financially Distressed Companies" in Ziegel JS (ed) Current Developments in International and Comparative Corporate Insolvency Law (Oxford Oxford University Press 1994) 109-183

Loubser 2013 SA Merc LJ

Loubser A "Tilting at Windmills? The Quest for an Effective Corporate Rescue Procedure in South African Law" 2013 SA Merc LJ 435-457

Markovits 2005 Cornell Int'l LJ

Markovits I "Exporting Law Reform - But Will It Travel?" 2005 Cornell Int'l LJ 95-114

Martin 2003 Am Bankr Inst L Rev

Martin N "Common-Law Bankruptcy Systems: Similarities and Differences" 2003 Am Bankr Inst L Rev 367-410 
Martin 2005 BC Int'l \& Comp L Rev

Martin N "The Role of History and Culture in Developing Bankruptcy and Insolvency Systems: The Perils of Legal Transplantation" 2005 BC Int'l \& Comp L Rev 1-78

McCormack Corporate Rescue Law

McCormack G Corporate Rescue Law - An Anglo-American Perspective (Edward Elgar Cheltenham 2008)

Metzger and Bufford 1993 Cal Bankr J

Metzger JM and Bufford SL "Exporting United Stated Bankruptcy Law: The Hungarian Experience" 1993 Cal Bankr J 153-159

Miller 2003 Am J Comp L

Miller JM "A Typology of Legal Transplants: Using Sociology, Legal History and Argentine Examples to Explain the Transplant Process" 2003 Am J Comp L 839-885

Mistelis 2000 Int'l Law

Mistelis LA "Regulatory Aspects: Globalization, Harmonization, Legal Transplants, and Law Reform - Some Fundamental Observations" 2000 Int'l Law 1055-1069

Moss 1997-1998 Brook J Int'l L

Moss G "Comparative Bankruptcy Cultures: Rescue or Liquidation? Comparison of Trends in National Law - England" 1997-1998 Brook J Int'l L 115-138

Olver Judicial Management

Olver AH Judicial Management in South Africa (PhD-thesis University of Cape Town 1980)

Osode 2015 Penn State J L Int'l Affairs

Osode PC "Judicial Implementation of South Africa's New Business Rescue Model: A Preliminary Assessment" 2015 Penn State J L Int'l Affairs 459-488

Pretorius and Du Preez 2013 SA J Entrep \& Small Bus Man

Pretorius $M$ and Du Preez W "Constraints on Decision Making Regarding Post-commencement Finance in Business Rescue" 2013 SA J Entrep \& Small Bus Man 168-191 
Rajak and Henning 1999 SALJ

Rajak H and Henning J "Business Rescue for South Africa" 1999 SALJ 262287

Richardson, Gallagher and Szekely 2008 JIBFL

Richardson F, Gallagher A and Szekely A "Chapter 11: One Size Fits All?" 2008 JIBFL 457-463

Rochelle 1996 TSAR

Rochelle MR "Lowering the Penalties for Failure: Using the Insolvency Law as a Tool for Spurring Economic Growth: The American Experience, and Possible Uses for South Africa" 1996 TSAR 315-330

Rushworth 2010 Acta Juridica

Rushworth J "A Critical Analysis of the Business Rescue Regime in the Companies Act 71 of 2008" 2010 Acta Juridica 375-408

Skeel 2004 Wash U LQ

Skeel DA "Employees, Pensions, and Governance in Chapter 11" 2004 Wash U LQ 1469-1483

Stein and Everingham New Companies Act

Stein C and Everingham G New Companies Act, Unlocked (Siber Ink Cape Town 2011)

Tabb 1986 S Cal L Rev

Tabb CJ "A Critical Reappraisal of Cross-collateralisation in Bankruptcy" 1986 S Cal L Rev 109-175

Tabb 1995 Am Bankr Inst L Rev

Tabb CJ "The History of the Bankruptcy Laws of the United States" 1995 Am Bankr Inst L Rev 5-51

Tabb 2013 U III L Rev

Tabb CJ "Credit Bidding, Security, and the Obsolescence of Chapter 11" 2013 U III L Rev 103-150

Tabb 2015 U III L Rev

Tabb CJ "The Bankruptcy Clause, the Fifth Amendment, and the Limited Rights of Secured Creditors in Bankruptcy" 2015 U III L Rev 765-810

Telesca 1988 Bankr Dev J

Telesca NB "Section 364(d) Superpriority Financing: Has a Secured Creditor met His Match?" 1988 Bankr Dev J 109-129 
Triantis 1997 NY Sch J Int'l \& Comp L

Triantis GG "The Careful Use of Comparative Law Data: The Case of Corporate Insolvency Systems" 1997 NY Sch J Int'l \& Comp L 193-205

Wallis 2010 SALJ

Wallis M "What's in a Word? Interpretation through the Eyes of Ordinary Readers" 2010 SALJ 673-693

Walters 2015 U III L Rev

Walters AJ "Statutory Erosion of Secured Creditors' Rights: Some Insights from the United Kingdom" 2015 U III L Rev 543-570

Watson Legal Transplants

Watson A Legal Transplants: An Approach to Comparative Law (Scottish Academic Press Edinburgh 1974)

Watson $1976 L Q R$

Watson A "Legal Transplants and Law Reform" 1976 LQR 79-84

Weintraub and Resnick Bankruptcy Law Manual

Weintraub B and Resnick AN Bankruptcy Law Manual $3^{\text {rd }}$ ed (Warren, Gorham and Lamont Boston 1992)

Wessels 2014 Insolvency Intelligence

Wessels B "Themes of the Future: Rescue Businesses and Cross Border Cooperation" 2014 Insolvency Intelligence 4-9

Case law

South Africa

ABSA Bank Limited v Newcity Group (Pty) Ltd 20133 All SA 146 (GSJ)

African Banking Corporation of Botswana v Kariba Furniture Manufacturers 20155 SA 192 (SCA)

Bothma-Batho Edms Bpk v S Bothma \& Seun Transport (Edms) Bpk 2014 2 SA 494 (SCA)

Investigating Directorate: Serious Economic Offences v Hyundai Motor Distributors (Pty) Ltd. In re: Hyundai Motor Distributors (Pty) Ltd v Smit 2001 1 SA 545 (CC) 
Kritzinger v Standard Bank of South Africa Ltd 2013 ZAFSHC 215 (19 September 2013)

Maset/ha $v$ President of the Republic of South Africa 20081 BCLR 1 (CC)

Merchant West Working Capital Solutions (Pty) Ltd $v$ Advanced Technologies and Engineering Company (Pty) Ltd 2013 ZAGPJHC 109 (10 May 2013)

Natal Joint Municipal Pension Fund v Endumeni Municipality 20124 SA 593 (SCA)

Redpath Mining South Africa (Pty) Ltd v Marsden 2013 ZAGPJHC 148 (14 June 2013)

\section{United States}

In re Alyucan Interstate Corp 12 Bankr 803 (Bankruptcy Court, Utah Division 1981)

In re Ames Department Stores Inc 115 BR 34 (Bankruptcy Court, New York Division 1990)

In re Aqua Associates 123 BR 192 (Bankruptcy Court, Pennsylvania Division 1991)

In re Campbell Sod Inc 378 BR 647 (Bankruptcy Court, Kansas Division 2007)

In re Dunes Casino Hotel 69 BR 784 (Bankruptcy Court, New Jersey Division 1986)

In re Fontainebleau Las Vegas Holdings LLC 434 BR 716 (District Court, Miami Florida Division 2010)

In re Saybrook Manufacturing Co Inc 963 F 2d 1490 (Court of Appeal, Eleventh Circuit 1992)

In re Sky Valley Inc 100 BR 107 (Bankruptcy Court, Gainsville Division 1988)

In re Snowshoe Company Inc 789 F 2d 1085 (Court of Appeal, Fourth Circuit 1986) 
In re Swedeland Development Group Inc 16 F 3d 552 (Court of Appeal, Third Circuit 1994)

In re Texlon 596 F 2d 1092 (Court of Appeal, Second Circuit 1979)

In re Vanguard Diversified Inc 31 BR 364 (Bankruptcy Court, New York Division 1983)

United Savings Association of Texas $v$ Timbers of Inwood Forest Associates Ltd 484 US 365 (US Supreme Court 1988)

\section{Legislation}

South Africa

Companies Act 46 of 1926

Companies Act 71 of 2008 and Regulations

Constitution of the Republic of South Africa, 1996

\section{United States}

Bankruptcy Reform Act, 1978

Title 11 "Bankruptcy" of the United States Code

International instruments

UNICTRAL Legislative Guide on Insolvency Law (2004)

\section{Government publications}

GN 1183 in GG 26493 of 23 June 2004

\section{Internet sources}

ABI date unknown https://abiworld.app.box.com/s/vvircv5xv83aavl4dp4h American Bankruptcy Institute date unknown Commission to Study the Reform of Chapter 11 (2012-2014) https://abiworld.app.box.com/s/vvircv5 xv83aavl4dp4h accessed 19 July 2016

Pretorius 2015 http://www.cipc.co.za/files/4714/2866/7900/Report_Number _3_ammended_30032015.pdf 
Pretorius M 2015 Business Rescue Status Quo Report http://www.cipc.co.za/files/4714/2866/7900/Report_Number_3_ammended _30032015.pdf_accessed 19 July 2016

\section{List of Abbreviations}

$\mathrm{ABI}$

Am Bankr Inst J

Am Bankr Inst L Rev

Am J Comp L

Bankr Dev J

BC Int'l \& Comp L Rev

Brook J Int'I L

JIBFL

Cal Bankr J

Cardozo L Rev

CIPC

Cornell Int'I LJ

DIP

DTI

Geo J Int'I L

Int'I Law

IODSA

KERP

LQR

MJECL

MLR

NY Sch J Int'I \& Comp L

PCF

Penn State J L Int'| Affairs

SA J Entrep \& Small Bus Man

SALJ

SA Merc LJ
American Bankruptcy Institute

American Bankruptcy Institute Journal

American Bankruptcy Institute Law Review

American Journal of Comparative Law

Bankruptcy Developments Journal

Boston College International and

Comparative Law Review

Brooklyn Journal of International Law

Butterworths Journal of International

Banking and Financial Law

California Bankruptcy Journal

Cardozo Law Review

Companies and Intellectual Property Commission

Cornell International Law Journal

Debtor in possession

Department of Trade and Industry

Georgetown Journal of International Law

International Lawyer

Institute of Directors of Southern Africa

Key employee retention plan

Law Quarterly Review

Maastricht Journal of European and

Comparative Law

Modern Law Review

New York Law School Journal of International and Comparative Law

Post-commencement finance

Penn State Journal of Law and International Affairs

South African Journal of Entrepreneurship and Small Business Management

South African Law Journal

South African Mercantile Law Journal 
SCA

$S$ Cal L Rev

Theo Inq $L$

TSAR

U III L Rev

U Penn J Bus L

UK

UNCITRAL

US

Vand L Rev

Yale LJ

Wash U LQ
Supreme Court of Appeal

Southern California Law Review

Theoretical Inquiries in Law

Tydskrif vir die Suid-Afrikaanse Reg / Journal of South African Law

University of Illinois Law Review

University of Pennsylvania Journal of

Business Law

United Kingdom

United Nations Commission on

International Trade Law

United States

Vanderbilt Law Review

Yale Law Journal

Washington University Law Quarterly 